Al-Manhaj: Jurnal Hukum dan Pranata Sosial Islam

Vol. : : 2 (1), 2020, 65-85

P-ISSN : 2686-1607

E-ISSN : 2686-4819

\title{
IMPLEMENTASI AKAD MUSAQOH PADA PENGELOLAAN TANAH PERHUTANI DENGAN SISTEM TASEN DI DUKUH WONOJATI DESA SUREN KECAMATAN MLARAK KABUPATEN PONOROGO
}

\author{
Nafi'ah \\ Institut Agama Islam Sunan Giri Ponorogo \\ email: nafiah490gmail.com
}

\begin{abstract}
Mu'amalah fiqh there are several types and types of contracts, one of which is the musaqoh (watering) contract. Likewise, the implementation of the contract in the tasen system between the land management community and Perhutani as the land owner in Hamlet Wonojati, Suren Village, Mlarak District, Ponorogo Regency. From the results of the study it was found that the implementation of the tasen system still uses manual intercropping farming techniques, in which the existence of the tasen system was responded to well by all members of the community. The implementation of the musaqoh contract in the management of Perhutani's land was in accordance with its terms and conditions and was shown from the Islamic attitudes and actions of both parties. Although there are some things that are not appropriate, this is done because of a compulsion.
\end{abstract}

Keywords: Tasen, Fiqih Mu'amalah, Musaqoh

Abstrak: Dalam fiqih mu'amalahada beberapa macam dan jenis akad, salah satunya akad musaqoh (penyiraman). Begitu juga pelaksaaan akad dalam sistem tasen antara masyarakat pengelola lahan dan Perhutani sebagai pemilik lahan di Dukuh Wonojati Desa Suren Kecamatan Mlarak Kabupaten Ponorogo. Dari hasil penelitian didapatkan bahwa pelaksanaan sistem tasen masih menggunkan teknik pertanian tumpang sari manual, yang mana keberadaan sistem tasen ini ditanggapi baik oleh seluruh warga masyarakat. Implementasi akad musaqoh pada kerjasama pengelolaan tanah milik Perhutani telah sesuai dengan syarat dan rukunnya serta ditunjukkan dari sikap dan tindakan Islami dari kedua 
belah pihak. Meskipun ada beberapa yang kurang sesuai hal tersebut dilakukan karena sebab keterpaksaan.

Kata Kunci: Tasen, Fiqih Mu'amalah, Musaqoh

\section{PENDAHULUAN}

Bidang ekonomi merupakan basis, sedangkan dua dimensi kehidupan masyarakat lainnya, yaitu institusi-institusi sosial dan bentuk-bentuk kesadaran lainnya merupakan bangunan atas. Oleh karena faktor penentu adalah basis, maka yang harus diperhatikan dahulu adalah bidang ekonomi. ${ }^{1}$ Mengingat betapa besarnya peranan bidang ekonomi terhadap segi-segi kehidupan masyarakat, maka yang harus diprioritaskan adalah bagaimana bidang ekonomi mampu berkembang dan tumbuh secara optimal sehingga nantinya masayarakat Desa Suren khususnya Dukuh Wonojati bisa hidup dalam keadaan yang sejahtera dan berkeadilan.

Demikian juga Realitas yang ada di Desa Suren Kecamatan Mlarak Kabupaten Ponorogo, dengan jumlah penduduk 2.367 yang mayoritas penduduknya menggantungkan hidup pada sistem tasen (berhak mengelola tapi tidak berhak menjual tanah milik perhutani dengan syarat-syarat tertentu) walaupun menurut persepektif masyarakat dukuh Wonojati khususnya keberadaan sistem tersebut sangat membantu perekonomian mereka, tapi secara realita perekonomian mereka sampai saat ini menurut hemat kami belum sejahtera, berdasarkan data dasar profil desa 
yang ada terdapat 440 KK yang hidup dalam keluarga pra sejahtera.

Seharusnya perekonomian warga Desa Suren umumnya dan warga Dukuh Wonojati kususnya yang secara geografis bersebelahan dengan hutan kayu putih dengan adanya sistem tasen jauh lebih sejahtera dan mandiri dari pada sekarang ini, dan mampu mencukupi segala kebutuhannya dengan memanfaatkan secara optimal terhadap pengelolaan SDA serta SDU yang ada. Dimana aparatur desa juga melakukan advokasi serta sering mengadakan penyuluhan-penyuluhan dengan bekerja sama dengan instansi-intansi terkait.

Selama ini akad sistem tasen yang bejalan di Dukuh Wonojati Desa Suren Kecamatan Mlarak yaitu masyarkat yang mengelola lahan tasen yang sering di sebut sebagai buruh tani, mereka berhak mendapat seluruh hasil lahan tanpa ada pembagian khusus antara pemilik lahan yaitu pihak perhutani akan tetapi ada pohon yang wajib di jaga dan dilestarikan di lahan perhutani selain tanaman palawija yaitu pohon kayu putih. Demikian juga tanaman palawija yang ditanam masyarakat, daun yang dihasilkan oleh pohon kayu putih sepenuhnya milik masyarakat.

Dalam penelitian ini, Peneliti memilih Dukuh Wonojati sebagai obyek penelitian. Secara geografis terletak di bagian Timur pusat Kota Ponorogo. Tepatnya di Dukuh Wonojati Desa Suren Kecamatan Mlarak. Yang merupakan satu-satunya desa yang masyarakatnya menggunakan sistem tasen sebagai sumber penghidupan. Sehingga dari hal tersebut diatas peneliti akan 
mencoba mendeskripsikan sejauhmana pelaksanaan akad yang terjadi dan sejauh mana masyarakat dalam penerapan yang sesuai dengan syari'at Islam.

\section{MEKANISME SISTEM TASEN DI DUKUH WONOJATI DESA SUREN KECAMATAN MLARAK}

Tasen atau yang dikenal masyarakat Suren dengan mbaon merupakan suatu bentuk kerjasama antara masyarakat pengelola lahan dan pighak perhutani sebagai pemilik lahan dengan syaratsyarat tertentu. Menurut cerita, banyak versi yang menyebutkan bahwa awal adanya sistem ini sekitar tahun 1965, dan ada juga yang menyebutkan sekitar tahun 1997/1998. Ini mungkin dipengaruhi oleh tingkat usia masing-masing informan, yang jelas keberadaan sistem tasen ini sudah sangat lama tetapi prosesnya berangsur-angsur, terkait dengan pembukaan hutan yang dilakukan perhutani sifatnya bertahap. Keberadaan sistem ini ditanggapi baik oleh seluruh masyarakat Desa Suren khususnya Dusun Wonojati. Dikarenakan adanya sistem ini sangat membantu terhadap peningkatan perekonomian masyarakat.

Pengelolaan lahan tasen, tidak jauh beda dengan sistem pertanian yang lain. Bedanya masyarakat menggunakan sistem tumpang sari dalam penanamannya, selain itu masyarakat dilarang menggunakan traktor maupun obat-obatan yang bisa membahayakan terhadap keberadaan tanaman perhutani yang berupa pohon kayu putih, mauni dan jati. Alasan pelarangan 
pemakaian traktor dan obat-obatan bisa merusak akar-akar pohon tanaman perhutani yang ada.

Tanaman tumpang sari yang biasa ditanam di lahan tasen umumnya jagung, ketela, kedelai dan kacang- kacangan. Hanya saja masyarakat dilarang menanam kacang panjang dengan alasan, pohonnya yang menjalar bisa merusak/ menjalar ketanaman kayu putih. Adapun perjanjian antara masyarakat pengelola lahan dan perhutani, dibuat secara tertulis dalam bentuk perjanjian kerjasama pengelolaan sumber daya hutan antara perum KPH (Kelompok Pengelola Hutan) Madiun dengan Masyarakat Pengelola Sumber Daya Hutan (MPSDH) Wonoharjo, Desa Suren Kecamatan Mlarak, Kabupaten Ponorogo. Yang di dalamnya terlampir secara detail mengenai anggaran dasar masyarakat pengelola sumber daya hutan (MPSDH) Wonoharjo desa Suren yang meliputi; (1) Nama, waktu dan tempat kependudukan, (2) Tujuan dan kegiatan, (3) Keanggotaan, (4) Keorganisasian, (5) Rapat-rapat, (6) Keuangan, (7) Lokasi, (8) Sanksi, (9) Aturan tambahan yang disusun dalam bentuk pasal-pasal yang terkait denganya. $^{2}$

Mengenai luas tanah tasen yang dikelola setiap masyarakat tidak sama, namun rata-rata setiap masyarakat mengelola setengah hektar (3,5 kotak). Pada mulanya pengelolaan lahan tasen dibuat sistem kontrak, tetapi sekitar tahun 90 an sistem kontrak dihapus, sehingga pengelolaan lahan tasen bisa tetap

${ }^{2}$ Dokumen Lampiran Perjanjian Kersasama Pengelolaan Sumber Daya Hutan, antara Perum KPH Madiun dengan Msyarakat Pengelola Sumberdaya Hutan (MPSDH) Wonoharjo, Desa Suren Kecamatan Mlarak. 
dilakukan selama tidak ada laranagan dari pihak perhutani untuk mengelola lahan.

Dalam hal pengawasan lahan tasen sepenuhnya tanggung jawab anggota MPSDH "Wonoharjo" dan umumnya masyarakat Desa Suren Kecamatan Mlarak, dan juga sebagai wadah bagi masyarakat pengelola lahan tasen, dimana badan ini dibentuk atas kerjasama antara perhutani KPH Madiun dengan masyarakat pengelolan lahan perhutani dengan tujuan sebagai berikut: (1) Meningkatkan pengetahuan/sumberdaya manusia (masyarakat desa hutan). (2) Meningkatkan penghasilan masyarakat disekitar hutan. (3) Melestarikan hutan dan lingkungan. (4) Untuk menjalin kerjasama dengan perhutani dalam pelaksanaan PHMB dan instansi terkait. (5) Menambah lapangan pekerjaan. ${ }^{3}$

Salah satu perjanjian antara masyarakat pengelola lahan dan pihak perhutani adalah bahwa masyarakat dibebaskan untuk menanami lahan tasen dengan tanaman apa saja yang mereka inginkan selama tidak merusak tanaman yang ada dan dilarang untuk menjual lahan tasen. Tetapi ada juga masyarakat yang melakukan semacam itu. Mereka menjual lahan tasen secara individu. Hal tersebut terpaksa dilakukan dengan berbagai alasan antara lain terdesak untuk mencukupi kebutuhan ekonomi dan tidak bisa melakukan hal lain selain menjual lahan tasen yang dimiliki, selain menjual lahan tasen alasan lainnya adalah ketidakmampuan fisik untuk mengelola lahan tasen. Ada juga yang

${ }^{3}$ Dokumen Lampiran Perjanjian Kersasama Pengelolaan Sumber Daya Hutan, antara Perum KPH Madiun dengan Msyarakat Pengelola Sumberdaya Hutan (MPSDH) Wonoharjo, Desa Suren Kecamatan Mlarak. 
menjual kepada saudara sendiri, dan ada juga yang menjualnya kemasyarakat di luar daerah. Padahal sebenarnya hal tersebut dilarang.

Selama ini sistem bagia hasil yang berjalan anatara masyarakat pengelola dan pihak perhutani yaitu masyarakat berhak mendapatkan seluruh hasil dari tanaman tumpang sarinya, yang benihnya dari masyarakat itu sendiri, sedangkan benih tanaman lahan tasen perhutani yang berupa daun kayu putih, dan mauni berasal dari perhutani dan hasilnya sepenuhnya milik perhutani. Sedangkan mereka yang bertugas memetik daun kayu putih bisa dari pengelola langsung maupun mereka yang bekerja sebagai buruh pemetik daun kayu putih dengan sistem upahnya per 1 kwintal daun kayu putih yang dihasilkan, pemitik mendapat Rp9000,- selain itu pengelola tidak dikenakan pajak atas lahan yang mereka kelola. Hanya saja ketika ada perbaikan jalan maupun fasilitas-fasilitas umum lainnya masyarakat diminta partisipasi untuk sumbangan dan tenaganya.

\section{ANALISIS AKAD SISTEM TASEN DI DUKUH WONO JATI DESA SUREN KECAMATAN MLARAK}

Sebagai makhluk sosial manusia tidak bisa lepas untuk tidak berhubungan dengan orang lain dalam rangka untuk memenuhi kehidupannya. Kebutuhan manusia yangberagam mamaksanya untuk berhubungan dengan orang banyak. Hubungan manusia yang satu dengan manusia yang lain dalam memenuhi kebutuhannya, harusnya ada aturan yang jelas terkait hak dan kewajiban keduanya berdasarkan kesepakatan. Proses 
untuk membuat kesepakatan dalam rangka untuk mencapai tujuan mereka masing-maisng, lazim disebut dengan proses untuk berakad atau melakukan kontrak perjanjian. Dalam pembahasan fiqih, akad kontrak yang dapat digunakan untuk bertransaksi sangat beragam, sesuai dengan karakteristik dan spesifikasi kebutuhan yang ada. ${ }^{4}$

Dalam hukum Islam untuk syahnya suatu perjanjian yaitu ketika terpenuhinya syarat dan rukunnya. Rukun merupakan syarat mutlaq yang harus dipenuhi dalam suati hal, peristiwa atau tindakan. Sedangakan syarat merupakan unsur yang harus ada dalam suatu hak, peristiwa, dan tindakan tersebut. ${ }^{5}$

Sebagaimana yang diterangkan di atas dapat peneliti analisa. Bahwasannya kerjasama antara masyarakat pengelola lahan dengan pihak perhutani sebagai pemilik lahan dengan syarat-syarat tertentu atau yang dikenal dengan sistem tasen (Mbaon) di Dukuh Wonojati Desa Suren Kecamatan Mlarak, Ponorogo, bisa dikategorikan sebagai suatu akad (perjanjian). Rukun-rukun akad dalam pelaksanaan sistem tasen meliputi:

1. Perhutani dan msyarakat Dukuh Wonojati Desa Suren Kecamatan Mlarak disebut sebagai al aqid (orang yang melakukan akad atau berakad) dimana seorang aqid harus memiliki kreteria khusus yang sudah di tetapkan oleh syara'. Secara umum masyarakat maupun pihak perhutani dipandang 47.

4Dimyauddin Djuwaini, Fiqih Mu'amalah (Yogyakarta: Pustaka Pelajar, 2008), ${ }^{5}$ Abdul Ghofur Ansori, Hukum Perjanjian Islam di Indonesia (Konsep, Regulasi Dan Implementasi) (Yogyakarta: Gajah Mada University Press, 2010), 24. 
telah cakap dan mampu untuk melakukan akad atau berakad. Jadi rukun akad yang pertam ini telah memenuhi ketentuan yang diatur dalam fiqih.

2. Sesuatu yang diakadkan (maqud alaih) dalam kerjasama antara masyarakat dan pihak Perhutani adalah lahan hutan. Dimana hak atas kepemilikan lahan adalah milik pemerintah yang diwakili oleh Perhutani. Dimana lahan hutan itu bisa disebut lahan milik negara. Terkait makna tanah negara menurut Islam berikut peneliti paparkan;

Pada asalnya seluruh tanah dalam wilayah negara Islam adalah milik negara, sebelun kemudian didistribusikan kepada pihak lain atau diubah status kepemilikannya. Negara sebagai pemegang amanah kekhalifahan punya kewajiban untuk menditribusikan dan memberdayakan tanah sedemikian rupa sehingga membawa kemanfaatan kepada masyarakat. Jenis tanah yang dikuasai negara pada masa Islam klasik dapat dikategorikan manjadi tanah tandus, tanah yang tidak terpakai dan tanah yang berasal dari daerah taklukan. ${ }^{6}$

Tanah negara ini (qithai) diberikan kepada: orang-orang yang mampu mengolah memperbaiki kehidupannya termasuk juga mu'alaf dan orang-orang yang bekerja sebagai abdi negara dan kegiatan sosial. Pemerian tanah negara kepada masyarakat bisa ditarik kembali apabila ternyata masyarakat tersebut tidak memanfaatkan tanah dengan baik. $^{7}$

${ }^{6}$ M.B. Hendrie Anto, Pengantar Ekonomi Mkro Islami (Yogyakarta: CV. Adi Pura, 2003), 213.

${ }^{7}$ M.B. Hendrie Anto, 214. 
Dari penjelasan diatas bahwasannya tanah hutan yang dipakai masyarakat dalam bercocok tanam diperbolehkan dalam Islam asalkan masyarakat mampu untuk menjaga dan melindunginya dengan baik. Untuk rukun yang kedua ini telah jelas bahwasannya objek akad yang dipakai dalam sistem tasen diperbolehkan dalam Islam.

3. Rukun akad yang ketiga tau yang terakhir adalah ijab dan qobul, menurut Ahmad Azhar Basyir, ijab adalah pernyataan pihak pertama mengenai isi perikatan yang didinginkan, sedangkan qobul adalah pernyataan pihak kedua untuk menerirmanya. ${ }^{8}$

Sehingga dapat peneliti analisa bahwa pihak pertama yang dimaksud dalam kerjasama pengelolaan lahan hutan (tasen) adalah pihak Perhutani (pemerintah) sedangkan pihak kedua yang dimaksud adalah msyarakat Dukuh Wonojati Desa Suren Kscamatan Mlarak. Adapun isi ijab dan qobul diwujudkan dalam sebuah akad perjanjian kerjasama pengelolaan sumberdaya hutan antara perum Perhutani KPH Madiun dengan Masyarakat Pengelola Sumber Daya Hutan (MPSDH) Wonoharjo, Desa Suren Kecamatan Mlarak Kabupaten Ponorogo. Yang mana dalam akad perjanjian telah disebutkan secara detail terkait semua hal yang meliputi:

Nama, waktu dan tempat kependudukan, tujuan dan kegiatan, keanggotaan, keorganisasian, rapat-raoat, keuangan, 
lokasi sanksi, dan aturan tambahan. Serta disusun dalam sebuah pasal-pasal yang terkait dengannya.

Aturan-atuaran yang telah disepakati oleh kedua belah pihak tersebut dapat dikatakan sah apabila antara Perhutani dan masyarakat pengelola lahan mampu untuk menjalankan hak dan kewajiban masing-masing sesuai dengan kesepakatan. Hak merupakan pemberian wewenang kepada seseorang untuk melakukan sesuatu, sedangkan kewajiban merupakan sesuatu yang sifatnya memaksa atau harus dilakuakan oleh seseorang. ${ }^{9}$

Masyarakat pengelola hutan berhak dan bebas untuk mengelola lahan dengan tanaman apa saja yang mereka kehendaki selama tidak mengganggu keberadan tanaman Perhutani yang berupa pohon kayu putih, jati dan mauni. Selain itu masyarakat berhak mendapatkan keseluruhan hasil dari tanaman tumpang sari yang ada. Sedangkan Perhutani berhak atas keseluruhan hasil dari tanaman Perhutani miliknya. Tanpa ada pembagian diantara keduanya.

Sedangkan kewajiban-kewajiban telah diatur dalam lampiran perjanjian. Diantara kewajiban tersebut, masyarakat dilarang untuk menjual lahan milik perhutani dengan alasan apapun. Jika hal tersebut dilakukan, maka masyarakat yang bersangkutan berhak untuk mendapat sanksi sesuai dengan kesepakatan. Selain itu masyarakat diharapkan mampu berpartisipasi aktif dalam pengelolaan lahan, dari penyusunan

${ }^{9}$ Faisal Badroen, Etika Bisnis dalam Islam (Jakarta: Kencana Prenada Media Grup, 2007), 72. 
rencana micro sampai pemanenan meliputi pengawasan dan penjagaan tanaman dan lahan perhutani.

Ciri-ciri kerjasama dalam Islam tidak dilihat dari label melainkan penerapan akhlaq Islam didalamnya. Berikut adalah asas-asas hukum perjanjian dalam konteks hukum Islam, meliputi: 1. Al-hurruriyah (kebebasan)

Asas ini merupakan prinsip dasar dakam hukum perjanjian Islam, dalam artian para pihak bebas membuat sesuatu perjanjian atau akad (freedom of making contract). Bebas dalam menentukan objek perjanjian dan bebas menentukan dengan siapa ia akan membuat perjanjian, dan bebas dalam menentukan penyelesaian sengketa jika terjadi dikemudian hari. Dimana itu dibatasi oleh ketentuan syari'at Islam.

2. Al-musawah (persamaan dan kesetaraan)

Asas ini mengandung pengertian bahwa para pihak mempunyai kedudukan (bargaining position) yang sama, sehingga dlam menetukan term and condition dari suatu akad atau perjanjian setiap pihak mempunyai kesetaraan atau kedudukan yang seimbang.

3. Al-'adalah (keadilan)

Pelasanaan asas ini dalam suatu perjanjian/ akad menuntut para pihak untuk melakukan yang benar dalam pengungkapan kehendak dan keadaan, memenuhi semua kewajibannya. Perjanjian harus senantiasa mendatangkan keuntungan yang adil dan seimbang, serta tidak boleh mendatangkan kerugian bagi salah satu pihak. 
4. Al-ridha (kerelaan)

Asas ini menyatakan bahwa segala transaksi yang dilakukan harus atas dasar kerelaan antara masing-maisng pihak dan tidak boleh ada unsur paksan, tekanan, penipuan, dan misstatemen.

5. Ash-shidiq (kebenaran dan kejujuran)

Bahwa dalam islam dilarang melakukan penipuan dan kebohongan, karena keduanya sangat berpengaruh dalam keabsahan perjanjian/akad.

6. Al-kitabah (tertulis) ${ }^{10}$

Bahwa setiap perjanjian dibuat secara tertulis, lebih berkaitan demi kepentingan pembuktian jika dikemudian hari terjadi sengketa.

Dari uraian diatas dapat dijelaskan bahwasannya akad sistem tasen telah sesuai dengan asas-asas hukum perjanjian Islam. Ditunjukkan dari sikap dan tindkan masyarakat maupun Perhutani yang senantiasa menjalankan isi perjanjian dengan penuh tanggung jawab dan kerelaan (al-ridha). Meskipun ada halhal yang kurang sesuai salah satunya ada masyarakat yang dengan sengaja melakukan pelanggran terkait penjualan lahan tasen secara sembunyi-sembunyi, padahal hal tersebut merupakan tindakan yang melanggar asas ash-shidq (kebenaran dan kejujuran). Meskipun hal tersebut bisa merusak sah akad, tapi tindakan tersebut dilakukan karena sebab dharurat (keterpaksaan) yaitu untuk mencukupi kebutuhan hidup atau 
kondisi yang tidak memungkinkan untuk mengelola lahan (alasan fisik yang renta). Meskipun begitu individu yang membeli lahan tasen tersebut masih melaksanakan kewajibannya dengan tetap menjaga dan mengawasi keberadaan lahan dan tanaman perhutani, hal tersebut bisa dimaklumi atau di $m a{ }^{\prime} f u$ (dimaafkan).

\section{ANALISA IMPLEMANTASI AKAD MUSAQOH PADA PENGELOLAAN TANAH PERHUTANI DENGAN SISTEM TASEN DUKUH WONOJATI DESA SUREN KECAMATAN MLARAK KABUPATEN PONOROGO}

Prof. Musthafa Ahmad Az-Zarqa' menyebutkan bahwasannya aspek-aspek hukum Islam dibagi menjadi tujuh kelompok, yang slah satunya adalah hukum-hukum yang berhubungan dengan pergaulan hidup dalam masyarakat mengenai kebendaan dan hak-hak serta penyelesaian persengketaan-persengketaan, seperti perjanjian jual beli, sewa menyewa, utang-piutang, gadai, hibah dan sebagainya. Kelompok hukum ini disebut hukum mu'amalah. ${ }^{11}$

Seperti yang telah diterangkan sebelumnya bahwasannya Islam merupakan agama yang universal, yang mana telah mengatur seluruh aktivitas umatnya. Demikian juga terkait hubungan dengan sesamanya diatur secara khusus dalam fiqih mu'amalah.

11Ahmad Azhar Basyir, Asas-asas Hukum Mu'malah (Hukum Perdata Islam) (Yogyakarta: UII Press Yogyakarta, 2004), 7. 
Pengetian fiqih mu'amalah maknanya adalah fiqih yang mengatur hubungan antar individu dalam sebuah masyarakat. ${ }^{12}$ Rachmad Syafei dalam bukunya fiqih mu'amalah berpendapat bahwasannya fiqih mu'amalah adalah aturan-aturan (hukum) Allah Swt. yang ditujukan untuk mengatur kehidupan manusia dalam urusan keduniaan atau urusan yang berkaitan dengan urusan duniawi dan sosial kemasyarakatan. ${ }^{13}$

Sedangakan ruang lingkup fiqih mu'amalah meliputi; ruang lingkup mu'amalah adabiyah dan ruang lingkup fiqih mu'amalah adabiyah adalah ijab dan kabul, saling meridhai, tidak ada keterpaksan dari slah satu pihak, hak dan kewajiban, kejujuran, penipuan, pemalsuan, penimbuan dan segala sesuatu yang bersumber dari indera manusia yang ada kaitannya dengan peredaran harta. ${ }^{14}$

Sedangkan ruang lingkup madiyah meliputi: jual beli (alba'i at-tijaroh), gadai (rahn), jaminan dan tanggungan (kafalah dan dhaman), pemindahan hutang (hiwalah), jatuh bangkit (tafjis), batas bertindak (al-hajru), perkongsian (asy-syirkah), perseroan hrata dan tenaga (al-mudharabah), sewa menyewa tanah (almusyaqoh dan al-mukhabarah) dan sebaginya. ${ }^{15}$

Selama ini akad yang terjadi antara masyarakat sebagai pengelola lahan dan Perhutani sebagai pemilik lahan dalam pengelolaan lahan Perhutani di Dukuh Wonojati Desa Suren Kacamatan Mlarak Kabupaten Ponorogo disebut sebagai sistem

${ }^{12}$ Ghufron A. Mas'adi, Fiqih Mu'amlah Konseptual (Semarang: PT. Raja Grafindo Persada, 2002), 1.

${ }^{13}$ Rachmad Syafei, Fiqih Mu'amalah (Bandung: CV. Pustaka Setia, 2006), 15.

14 Rachmad Syafei, 18.

15 Rachmad Syafei. 
tasen (mbaon). Masyarakat dibebaskan untuk mengelola lahan Perhutani dengan menanami tanaman apa saja yang mereka kehendaki. Dengan ketentuan tanaman tersebut tidak mengganggu atau merusak keberadaan tanaman perhutani yang meliputi pohon kayu putih, jati dan mauni. Dimana sistem pengeloaannya yaitu benih tanaman milik Perhutani berasal dari Perhutani, sedangkan yang menanam adalah masyarakat pengelolaan lahan tersebut. Jelasnya masyarakat hanya bertanggung jawab untuk menjaga dan mengawasinya atau sekedar menyirami dan merawat tanaman milik perhutani tersebut.

Dari sini dapat peneliti analisa bahwasannya akad yang terjadi antara masyarakat Dukuh Wonojati Desa Suren Kecamatan Mlarak dengan pihak Perhutani dengan syarat-syarat tertentu bisa dikategorikan sebagai akad musaqoh.

Terkait musaqoh ini terdapat beberapa khilafiyah (perbedaan pendapat) dari para ulama mengenai boleh tidaknya transaksi musaqoh, diantaranya: Menurut ulama Hanafiyah musaqoh sama seperti muzaro'ah, baik dalam hukum dan persyaratan terjadinya musaqoh. Menurut Abu Hanifah dan Zufar Ibn Huzail berpendirian bahwa akad musaqoh dengan ketentuan petani penggarap mendapatkan sebagian dari kerjasama ini tidak sah, karena musaqoh seperti ini termasuk mengupah seseorang dengan imbalan sebagian hasil yang akan dipanen dari kebun itu. ${ }^{16}$ Ketidak bolehan itu didasarkan pada hadist yang artinya; 20027), 282.

16Nasroen Haroen, fiqih mu'amlah (Jakarta: Gaya Media Pratama Jakarta, 
"Barang siapa yang memiliki tanah, hendaklah mengelolanya, tidak boleh menyewakannya dengan sepertiga atau seperempat, dan tidak pula dengan makanan yang telah ditentukan". (Muttafaq Alaih) ${ }^{17}$

Jumhur ulama fiqih, termasuk Abu Yusuf dan Muhammad Ibbn AlHasan Asy-Syaibani, keduanya tokoh fiqih Hanafi, berpendirian bahwa akad musaqoh diperbolehkan. ${ }^{18}$ Dimana dasar kebolehan musaqoh menurut mereka didasarkan pada hadist dari 'Abdullah Ibn 'Umar, manyatakan yang artinya;

"Bahwa Rosulullah SAW, malkukan kerjasama perkebunan dengan penduduk Khaibar dengan ketentuan bahwa mereka mendapatkan sebagian dari hasil atau pertanian itu". (HR. AlJama'ah (mayoritas pakar hadist). Selain hadist, dasar kebolehan musaqoh juga didasarkan atas ijma'; karena sudah merupakan transaksi yang amat dibutuhkan oleh umat untuk memenuhi keperluan hidup mereka.

Seperti haknya yang dijelaskan oleh An-Nabhani dalam bukunya Membangun Sistem Ekonomi Alternatif Perspektif Islam, bahwasannya yang termasuk dalam kategori bekerja adalah musaqoh, yaitu pembayaran dari hasil panen pohon milik seseorang kepada orang lain, agar orang yang bersangkutan menyiraminnya. Kerja yang dibutuhkan oleh pihak pemilik tanaman atau pepohonan. Ini kemudian diberi kompensasi tertentu dari hasil panen miliknya, kerja semacam ini disebut dengan musaqoh. ${ }^{19}$

17 Rachmad Syafei, Fiqih Mu'amalah, 212-213.

${ }^{18}$ Nasroen Haroen, fiqih mu'amlah, 282.

${ }^{19}$ Taqyuddin An-Nabhani, Membangun Sistem Ekonomi Alternatif Perspektif Islam (Surabaya: Risalah Gusti, 2002), 82. 
Dari berbagai pendapat diatas dapat peneliti analisa bahwasanya musaqoh ini diperbolehkan yang mana didasarkan pada pendapat Jumhur Ulama Fiqih, termasuk Abu Yusuf dan Muhammad Ibbn Al-Hasan Asy-Syaibani diatas serta hasil Ijma' para ulama'.

Sedangkan pendapat ulama yang tidak memperbolehkan transaksi musaqoh ini perlu kita analisa lebih mendalam kembali. Sebagaimana yang dikutip dari buku Fiqih Sosial Kiai Sahal Mahfudh Antara Konsep Dan Implentasi, diterangakn bahwasanya saat ini telah banyak persoalan yang membutuhkan penjelasan secara mendalam dari kitab-kitab kuning. Dimana hal tersebut memerlukan beberapa tahapan. ${ }^{20}$

Seperti halnya menelusuri sebab terjadinya perbedaan pendapat para ulama. Beliau menjelaskan perlu ada pengkajian mendalam terkait perbedaan tersebut, mulai dari asbabul nuzul, asbabul wurud, sejarah kodifikasi kitab kuning, latar belakang pendidikan pengarang, keadaan sosial, budaya dan politik yang mempengaruhinya, dan faktor serta tujuan pengarang mengemukakan pendapatnya. Selain itu melakukanan analisa mendalam apakah pendapat ulama itu murni dari refleksi teks atau ada faktor lain yang mempengaruhinya.

Berikut analisa peneliti terkait sistem bagi hasilnya; banyak yang mengatakan bahwasannya kompensasi atau bagi hasil dalam

20Jamal Ma'mun Asmani, Fiqih Sosial Kiai Sahak Mahfudh Antara Konsep dan Implementasi (Surabaya: Khalista, 2007), 105-106. 
akad musaqoh yaitu hasil dari tanamn tersebut dengan prosesntase sesuai dengan kesepakatan.

M. Ali Hasan dalam bukunya berbagai transaksi dalam Islam menerangkan bahwasannya syarat-syarat yang harus dipenuhi oleh masing-masing rukun akad, dimana terkait bagi hasil (kompensasi) dalam akad musaqoh bahwsannya ada ketentuan pasti tentang pembagian pengelola. Prosentasenya harus jelas untuk masing-masing pihak. Dengan demikian tidak sah akad itu, apabila mencantumkan bagian pengelola saja atau pemilik lahan (kebun) saja. ${ }^{21}$

Meskipun sistem bagi hasil dalam pengelolan lahan tasen tidak berasal dari hasil tanaman pemilik lahan, tetapi bagi hasilnya dari tanaman tumpang sari yang ditanam disela-sela tanaman milik Perhutani, hal tersebut diperbolehkan dalam Islam. Karena sahnya suatu akad tergantung dari kedua belah pihak yang berakad (al-aqid). Ketika al aqid sudah menyatakan kesepakatan isi dalam perjanjian secara tidak langsung masyarakat telah menyatakan ikrar persetujuan dan kerelaan untuk menjalankan akad (perjanjian) sesuai dengan kesepakatan bersama.

Dari sini telah jelas bahwasannya akad kerjasama antara masyarakat sebagai pengelola lahan dan Perhutani sebagai pemilik lahan dengan syarat-syarat tertentu dalam sistem tasen diperbolehkan dalam Islam, seta di kategorikan sebagai bentuk kerjasama pengeloaan lahan atau dikenal dengan istilah Fiqih mu'amalah sebagai akad musaqoh.

21M.Ali Hasan, Berbagai Transaksi dalam Islam (Fiqih Mu'amalah) (Jakarta: PT. Raja Grafindo Persada, 2004), 283. 


\section{KESIMPULAN}

Mekanisme pengelolaan sistem tasen di Dukuh Wonojati Desa Suren Kecamatan Mlarak Kabupate Ponorogo menggunakan teknik pertanian tumpang sari manual, yang mana keberadaan sistem tasen ini ditanggapi baik seluruh warga Dukuh Wonojati Desa Suren Kecamatan Mlarak. Perspektif fiqih Mu'amlah terhadap mekanisme akad sistem tasen di Dukuh Wonojati Desa Suren Kacamatan Mlarak telah sesuai dengan konsep dan asas-asas akad menurut ajaran Islam, dan akad tasen dikategorikan sebagai bentuk kerjasama pengelolaan lahan (tanah) dengan cara memelihara (menyirami) atau yang dikenal dengan musaqoh dengan sistem bagi hasil sesuai kesepakatan.

\section{DAFTAR PUSTAKA}

An-Nabhani, Taqyuddin. Membangun Sistem Ekonomi Alternatif Perspektif Islam. Surabaya: Risalah Gusti, 2002.

Ansori, Abdul Ghofur. Hukum Perjanjian Islam di Indonesia (Konsep, Regulasi dan Implementasi). Yogyakarta: Gajah Mada University Press, 2010.

Anto,M.B. Hendrie. Pengantar Ekonomi Mkro Islami. Yogyakarta: CV. Adi Pura, 2003.

Asmani, Jamal Ma'mun Fiqih, Sosial Kiai Sahak Mahfudh antara Konsep dan Implementasi. Surabaya: Khalista, 2007.

Badroen, Faisal. Etika Bisnis dalam Islam. Jakarta: Kencana

Prenada Media Grup, 2007.

Basyir, Ahmad Azhar. Asas-asas Hukum Mu'malah (Hukum Perdata Islam). Yogyakarta: UII Press Yogyakarta, 2004.

Djuwaini, Dimyauddin. Fiqih Mu'amalah. Yogyakarta: Pustaka Pelajar, 2008.

Dokumen Lampiran Perjanjian Kersasama Pengelolaan Sumber Daya Hutan, antara Perum KPH Madiun dengan 
Masyarakat Pengelola Sumberdaya Hutan (MPSDH) Wonoharjo, Desa Suren kecamatan Mlarak.

Haroen, Nasroen. Fiqih Mu'amlah. Jakarta: Gaya Media Pratama Jakarta, 2007.

Kristeva,Santoso. Manifesto Wacana Kiri. Yogyakarta: Inphisos, 2007.

M. Ali Hasan, Berbagai Transaksi dalam Islam (Fiqih Mu'amalah). Jakarta: PT. Raja Grafindo Persada, 2004.

Mas'adi, Ghufron A. Fiqih Mu'amlah Konseptual. Semarang: PT. Raja Grafindo Persada, 2002.

Syafei, Rachmad. Fiqih Mu'amalah. Bandung: CV. Pustaka Setia, 2006. 